\title{
BREEDING, GENETIC AND GENOMIC OF CITRUS FOR DISEASE RESISTANCE ${ }^{1}$
}

\author{
MARCOS A. MACHADO², MARIÂNGELA CRISTOFANI-YALY², MARINÊS BASTIANEL²
}

ABSTRACT - Although the citriculture is one of the most important economic activities in Brazil, it is based on a small number of varieties. This fact has contributed for the vulnerability of the culture regarding the phytosanitary problems. A higher number of varieties/genotypes with potential for commercial growing, either for the industry or fresh market, has been one of the main objectives of citrus breeding programs. The genetic breeding of citrus has improved, in the last decades, due to the possibility of an association between biotechnological tools and classical methods of breeding. The use of molecular markers for early selection of zygotic seedlings from controlled crosses resulted in the possibility of selection of a high number of new combination and, as a consequence, the establishment of a great number of hybrids in field experiments. The faster new tools are incorporated in the program, the faster is possibility to reach new genotypes that can be tested as a new variety. Good traits should be kept or incorporate, whereas bad traits have to be excluded or minimized in the new genotype. Scion and rootstock can not be considered separately, and graft compatibility, fruit quality and productivity are essential traits to be evaluated in the last stages of the program. The mapping of QTLs has favored breeding programs of several perennial species and in citrus it was possible to map several characteristics with qualitative and quantitative inheritance. The existence of linkage maps and QTLs already mapped, the development of EST and BAC library and the sequencing of the Citrus complete genome altogether make very demanding and urgent the exploration of such data to launch a wider genetic study of citrus. The rising of information on genome of several organisms has opened new approaches looking for integration between breeding, genetic and genome. Genome assisted selection (GAS) involves more than gene or complete genome sequencing and is becoming an import support in breeding programs of annual and perennial species. An huge information amount can be derivate from genome analysis. The use and benefit of such informations will depend on the genetic basis of the breeding program.

Index terms: citriculture, improvement, hybrids.

\section{MELHORAMENTO, GENÉTICA E GENÔMICA DE CITROS PARA RESISTÊNCIA A DOENÇAS}

RESUMO - Embora a citricultura seja uma das mais importantes atividades econômicas no Brasil, ela está apoiada em um pequeno número de variedades. Este fato tem contribuído para sua vulnerabilidade, especial no que ser refere a fatores fitossanitários. A obtenção de um maior número de variedades, seja para a indústria seja para o mercado de fruta fresca, tem sido um dos principais objetivos dos programas de melhoramento. O melhoramento genético de citros tem sido ampliado nas últimas décadas em função da possibilidade de associação de ferramentas da biotecnologia e métodos clássicos de melhoramento. O uso de marcadores moleculares para a seleção precoce de plântulas zigóticas em cruzamentos controlados ampliou a possibilidade de seleção de maior número de novas combinações e, em consequência, o estabelecimento de grande número de híbridos em experimentos de campo. Quanto mais rápido novas ferramentas sejam incorporadas ao programa, mais rápido é a possibilidade de obter novos genótipos que possam ser testados como variedades. Características adequadas podem ser incorporadas ou mantidas, enquanto características indesejáveis podem ser excluídas ou minimizadas nos novos genótipos. Copas e porta-enxertos não podem ser considerados separadamente, e a compatibilidade de enxertia, qualidade de fruta e produtividade são características essenciais a serem avaliadas nos últimos estágios do programa. Mapeamento de características quantitativas (QTLs) tem propiciado os programas de melhoramento de várias espécies lenhosas perenes, e em

\footnotetext{
${ }^{1}$ Palestra Sinfruit 205(A) - Simpósio Internacional de Fruticultura - Avanços na Fruticultura (17 a 21 Outubro)

${ }^{2}$ Centro de Citricultura Sylvio Moreira Instituto Agronômico. E-mail: marcos@centrodecitricultura.br
} 
citros é possível mapear várias características com herança quantitativa e qualitativa. A existências de mapas de ligação e QTLs, o desenvolvimento de bibliotecas de ESTs e BACs, assim como o sequenciamento completo do genoma de citros, ampliam a urgência para exploração de tais dados para ampliar os conhecimentos sobre genética do grupo. $\mathrm{O}$ volume crescente de informações de genomas de vários outros organismos tem ampliado novas abordagens procurando a integração entre melhoramento, genética e genoma. Seleção assistida por genoma envolve mais que sequenciamento de genes ou genomas completos e tem se tornado uma importante ferramenta nos programas de melhoramento de espécies perenes e anuais. Um grande volume de informações pode ser derivada da análise de genomas. O uso e benefício de tais informações dependerá da base genética do programa de melhoramento.

Termos para indexação: citricultura, melhoramento, híbridos.evelopment of a clear understanding of hostpathogen interactions and other traits of interest.

\section{INTRODUCTION}

The citrus industry is one of most important agribusinesses in Brazil, with well organized segments represented by nurserymen, growers, input and machinery suppliers, third party services and contractors, factories for juice processing and fresh market chains, etc. Numbers that represent the industry are displayed on Table 1, and although the principal activity is the concentrated juice production, a typical commodity, Brazil has an expressive participation and control of the market. The State of Sao Paulo was always the major producer, processor and exporter.

With highly organized segments and competitive initiatives, the Brazilian citrus industry respond with annual gross income of around 1.5 billion dollars, from exports of concentrated juice and orange sub-products such as pectin, oil and animal food. The largest growth of the industry happened during the 1960s and 70s motivated by international demand, and increase in fruit production was largely achieved because of area expansion rather then productivity. The low yield obtained in Brazil (average of 2 boxes of $40.8 \mathrm{~kg} /$ tree/year) is strictly associated to simultaneous pest and disease outbreaks, which has raised production costs and forced changes in production system, traditionally based on non-irrigation and narrow genetic base of used cultivars.

The vast majority of sanitary problems that challenges the national citriculture are reflect of accelerated industry expansion, often without attention regarding biotic and abiotic limiting factors. The major biotic constrains include diseases such as CVC, citrus canker, leprosis, tristeza, black spot, sudden death, and more recently, huanglongbing (ex-greening), in addition to many pests. But other biotic factors deserve attention and are associated to characteristics of individual citrus groups, which needs better understanding to support future work on plant breeding, for instance, fruit quality (color, composition and nutritional characteristics). Among abiotic limiting factors, nutritional and other stresses are relevant.

The group named citrus has great diversity in genus, species, varieties and clones, however a relatively small number is used on commercial groves nowadays mainly because of botanical and historical reasons. Commercially used species are propagated only vegetativaly (buds for scion cultivars and nucellar seeds for rootstocks), and thus, citrus has had massal selection of mutants as the fastest way of breeding. Traditional programs of genetic improvement using hybridization and recurrent selection always met genetic difficulties (high heterozigosity, incompatibility, long cycle for selection, etc) and botanical barriers (mainly adventitious nuclear apomixis and juvenility) characteristic of citrus group.

The challenges in citrus breeding programs persist, in spite of advances in production in Brazil and elsewhere around the world. In reality, they turn even more critical because of expansion of the industry based on very low genetic variability and the impossibility to match constant outbreaks of pests and diseases, which has happened in the same proportion of the industry development. The need to expand the genetic base of used citrus nowadays, likewise the enhancement of the material in use, demand keeping and promoting breeding programs based on biotechnological tools.

Citrus diseases can be considered the most limiting constraint to increase and sustain productivity in many areas around the world. Such factors have increased importance depending on how large new plantings are using monospecific and monoclonal citrus types, and normally abiotic stress pressures deteriorate this situation even more. Among important characteristics associated to severity of pests and diseases are the narrow genetic base used by the industry, the high genetic plasticity of the group with high capacity of adaptation to different conditions, including new biotic interactions (new pathogens), 
and propagation practices, specially grafting of buds and seeds with nucellar embryos.

\section{CITRUS BREEDING PROGRAM: CHAL- LENGES}

To the genus Citrus belong a great number of species which systematic classification is not clear until nowadays. The group was classified in six (Linnaeus), 16 (Swingle) or 163 (Tanaka) species, respectively. But some studies with molecular markers have shown that there are only three typical species: mandarin (C. reticulata), pummelo ( $C$. grandis) and citron (C. medica). The other species seem to be natural hybrids, including sweet orange, the more important species for the citrus industry in Brazil.

Although there is high diversity genetic within the group, only few species and clones are used as commercial varieties either as scion or rootstock. Since no longer exist natural areas of occurrence of citrus native species, the genetic variability is well represented in germplasm collections that have been maintained and used as support for breeding. However, despite the high genetic diversity in several germplasm collections, breeding programs of citrus species still remain a challenge. Such challenges can be characterized in different categories:

- Botanic. Citrus are exotic plants in Brazil and several other countries. In their origin centers (China and India) there are not more native plants, which could be collected to introduce new genetic variability in the group. Thus, the genetic variability can only be accessed in germplasm collections around the world. Citrus are woody and perennial trees, and hence field experimentations need areas, and long time to be concluded. Citrus species present juvenility characterized by vigorous growth, lack of blossom flowers during several years (can reach ten years), presence of thorns, first fruits without commercial value, differentiated leaf morphology etc. Adventitious nucellar poliembriony occurs in almost all citrus species with production of apomitic seeds which embryos are juvenile clones of the mother plant.

- Genetic. Important citrus species as sweet oranges present high heterozigozity pointed out the hybrid origin of such species. Besides the usual endogamy after crossing between heterozygous genotypes, inter- and intraspecific hybrids of them frequently present segregation of desirable traits. Sexual incompatibility, male or female sterility can also occur within the species. Although apomixis can be considered a mechanism maintaining the hetero- zigozity of a genotype, in the citrus species it is a barrier to improve the genetic variability. Moreover apomitic embryos usually are more vigorous than the zygotic ones. On the other hand, even when the sexual embryos survive, they should be screened and selected from the nucellar embryos. Such selection can be carried out using morphological traits (leaf traits used in crossing of Citrus and Poncirus), biochemical (isozymes) or molecular (DNA based) markers. Another aspect to be taken in consideration is the lack of information on the inheritance of important traits such as disease resistance or fruit quality. Many of these traits seem to have complex genetic regulation and, therefore, are quantitative traits loci (QTLs) regulated by several genes with accentuated effect of environment. Although there are great challenges to approach traditional breeding, genetic variability can be increased by using of natural mutants that arise from somatic mutation, known as bud sports as well. Stable mutations in somatic tissues may arise enough genetic variability to characterize new variety. Classical example is the Baianinha sweet orange, which arose from Baía, which is a somatic mutant from Seleta sweet orange.

- Agronomic. Since the citrus industries, specially the production of juice for exportation, are the main users of the fruit produced by the growers, they claim patterns of fruits quality (color, acidity, soluble solids, etc.) usually found in the common varieties. Any changes in such patterns are not welcome. Therefore, changes in the profile of scion varieties ask firmly for no great changes in the fruit patterns. On the other hand, rootstock varieties can be changed easier, mainly because such problems do not have other solution as changing the variety, for instance tristeza (sour orange changed by Rangpur lime), blight (Rangpur lime by mandarins), and sudden death (Rangpur lime by mandarins and citrumelos). Besides fruit quality, productivity is also an important trait to be considered in a breeding program. Both traits seem to have complex genetic inheritance, and are regulated by quantitative trait loci (QTL), with a strong environmental effect over their expression. Another agronomic aspect that should be pointed out relates with a way the citrus trees are propagated. Both rootstocks and scions varieties are vegetativaly propagated by apomitic seeds and grafting of budwoods, respectively. Although such propagation ways lead up to uniform orchads, they contribute to the maintenance of narrow genetic basis of the citrus industry in the world. Few commercial varieties, as consequence of the narrow genetic basis, mean also few morphological descriptors, hindering a suitable characterization of the phenotype and, troubling the 
protection right.

- Economic. World citrus industry is a chain of the agribusiness that includes growers, nurserymen, supplies, market of fresh fruit, juice processing plants, etc. In Brazil the industries of concentrated orange juice consume more than $75 \%$ of the orange production. Even represented by few groups of companies they are considered a great success in terms of agribusiness. Therefore, in such position it is difficult to change the patterns of production, including varieties profile. Only when the pressure of production costs (orange fruits) increase significativaly, and the productivity and production do not increase at the same time and proportion, they demand for new varieties.

In conclusion, breeding of such woody species should have different approaches as those used for annual ones, and should add biotechnological tools to accelerate genetic gains.

\section{CITRUS BREEDING PROGRAM: OVER- COMING THE CHALLENGES}

The challenges pointed out above have hindered citrus breeding programs worldwide, and the more important scion varieties were selected from budsport (somatic mutation). On the other hand, rootstock varieties have been selected on genetic breeding programs, either by selection in germplasm collection or production of sexual or somatic hybrids. But with new biological tools (biotechnology) it has been possible to make progress in the selection of new genotypes. Shortly, the following approaches have been used to overcome the challenges in citrus breeding.

Low genetic diversity in the origin centers $\rightarrow$ suitable maintenance and use of germplasm collections. In Brazil the more important citrus collection is at Centro de Citricultura Sylvio Moreira / IAC, in Cordeirópolis, with over 2000 accesses. With the increasing of protection rights around the world it has became difficult to exchange genetic material among the different collections.

Juvenility $\rightarrow$ It is lacking studies on physiological basis of juvenility in citrus species. From other woody plants it is possible to hypotheses that juvenility can overcome by stresses or by grafting.

Nucellar poliembriony (apomixis) $\rightarrow$ This trait can not be suppressed, but by use of morphological (leaf pattern, for instance) and molecular (biochemical or DNA based) markers sexual hybrids can be easy selected from the nucellar ones. When necessary embryos rescue in tissue culture can be tried.

High heterozigozity $\rightarrow$ Maybe the more im- portant trait hindering genetic gains. Since the genotypes (and the phenotypes) are fixed, any controlled cross between them will have high segregation rate of the agronomical traits as fruit quality and disease resistance. The greater the number of cross events, the higher, the possibility to get new suitable genetic combination.

Complex inheritance $\rightarrow$ The complexity of the inheritance of agronomical traits, as disease resistance and fruit quality, may be associated with our unknown about them. Approaching molecular markers, suitable population size and phenotype evaluation it has been possible to map several important traits in citrus species.

Somatic mutation $\rightarrow$ Does not disturb a breeding program, but should be better understood how it occurs at molecular level. May be it could be used as tool to improve genetic variability.

Scion varieties and fruit quality $\rightarrow$ The current pattern of fruit quality does not carry any change. Therefore, the challenge is to change the plant but not change the fruit!

Scion varieties and disease resistance $\rightarrow$ There are several demands for new scion varieties, especially disease resistance, without change in fruit quality.

Rootstock varieties $\rightarrow$ Can be easier changed, especially when there is not other way to overcome the problem many time associated with limiting diseases (tristeza, blight, sudden death) or high susceptibility to water stress.

Variety protection $\rightarrow$ Although Brazilian law has established a policy for variety protection (Lei de Proteção de Cultivares, Lei n 9.456, de 1997) it is not possible ask for protection of citrus species yet, because It depends on morphological (only) descriptors that are ready to be applied. As signatory of UPOV (The International Union for the Protection of New Varieties of Plants) convention Brazil does not accept molecular markers for genotyping plant species yet (!).

Economic $\rightarrow$ Perhaps the urgency to change the current model of citrus production would be exactly the urgency to solve problems associated to few varieties, increasing number of diseases and pests, low productivity and high cost of production.

\section{CITRUS BREEDING PROGRAM: AP- PROACHES}

Any approach for citrus breeding should have the basic assumption that the main goal of such program is to obtain new and with better performance variety (Fig. 1). The faster new tools are incorporated in the program, the faster is possibility to reach new 
genotypes that can be tested as a new variety. Good traits should be kept or incorporated, whereas bad traits have to be excluded or minimized in the new genotype. Scion and rootstock can not be considered separately, and graft compatibility, fruit quality and productivity are essential traits to be evaluated in the last stages of the program.

Exploring germplasm collections $\rightarrow$ That is main approach that has been employed in several programs around the world. Selected varieties from such collections account for the current variety profile. But the collections should be better explored especially for rootstocks and new hybrids. The citrus germplasm collection at the Citriculture Center in Cordeirópolis is considered the more complete and diverse in Brazil and from it originated the majority of the commercial varieties currently grown in Sao Paulo State.

Massal selection of mutants $\rightarrow$ May be the most efficiently way to get new varieties, especially from sweet orange, grapefruit and Satsuma, species with high rate of somatic mutation. But this approach is entirely casual, of a not controlled way, and has unknown mechanism.

Hybridization - It is always considered one the most important approach in citrus breeding. However, new hybrids have been not produced for commercial proposal, at least at large scale. The reasons for that are the challenges to select the sexual embryos, high heterozigozity of the parents, endogamy depression, and long juvenile period of such plants. Several tools of biotechnology nowadays help to overcome such problems. Intra and inter specific hybrids are useful both for potential new varieties and population map. Moreover sexual hybridization, somatic hybrids by protoplast fusion have been obtained as potential rootstock or tetraploid genotypes useful for crossing with diploids to produce seedless fruits (triploid).

Genetic maps $\rightarrow$ Genetic mapping is the only way to cover the entire genome without sequencing and to overview the complex relationships between genes and the environmental. It is a compulsory approach to be carried out to understand the inheritance of the resistance or susceptibility to biotic (diseases and pests) and abitioc (temperature, nutritional, water, etc.) stress, and to locate (map) important genes in the genome. Using molecular markers based on DNA (RAPD, AFLP, SSR, TRAP, SNP) it is possible to construct high saturated genetic maps, which can be associated with cloning of large genome fragments in BAC (bacterial artificial chromosome) libraries to trace and locate genes and their regulation pathways. Selection assisted markers (SAM) is already a usual approach in annual species.

Genome integration $\rightarrow$ The rising of information on genome of several organisms has opened new approaches looking for integration between breeding, genetic and genome. Genome assisted selection (GAS) involves more than gene or complete genome sequencing and is becoming an import support in breeding programs of annual and perennial species. Besides basic studies on gene regulation, genomic information's have been used for genotyping and genetic mapping with markers based on genome (especially single nucleotide polymorphism, SNP), studies on QTL expression and global gene expression using arrays, studies of sinteny among related species, etc. An huge information amount can be derivate from genome analysis. The use and benefit of such informations will depend on the genetic basis of the breeding program.

Genetic transformation $\rightarrow$ Is another approach to get new varieties at relatively short time period. The success of genetic transformation to breed citrus will depends on several factors, many of them outside of the program. Among the factors that can further stable transgenic citrus plants could be included: species easy to be transformed with Agrobacterium tumefaciens, although problems with juvenility should be overcame; in vitro regeneration and propagation is well established; genetic transformation does not change at large extension the original genotype and apparently the phenotype too. Among the challenges could be mentioned: as woody and perennial species a transformation event can be lost during the plant growth; lack of well characterized genes to be inserted into the genome; lack of tissue specific promoters that could support the gene expression according with its induction; many vectors, promoters and gene used for plant transformation are patented; the public perception for transgenic plants is still confuse and lacking information, specially orange juice that has a strong association with health. Thus, even the industry does not accept to be associated with research on genetic transformation.

\section{GENETIC OF BIOTIC AND ABIOTIC RE- SISTANCE IN CITRUS}

In order to understand the concept of resistance or susceptibility to biotic factors in citrus, it is necessary to consider that many diseases and pests are exclusively associated with the canopy (scion), the root system (rootstock), or even could be the result of the interaction between them. Therefore, any breeding program searching for resistance to a given 
pathogen must take into consideration the nature of the interaction being studied.

Even though the number of pathogenic organisms that cause diseases in citrus is significantly large, some of them are of particular interest due to the productivity losses associated to them and the elevated cost involved in their control. In Brazil the work carried out on breeding for resistance and genetic mapping have been focused on the following pathosystems: Citrus variegated chlorosis (CVC), Citrus leprosis virus (CiLV), Huanglonnbing (HLB, ex greening); Citrus sudden death (CSD), Citrus tristesa virus (CTV); Phytophthora Gummosis; Citrus canker; Citrus black spot and Alternaria brown spot.

Citrus variegated chlorosis - It is caused by Xylella fastidiosa as a result of its ability to colonize the xylem vessels and disrupt the transport of water and nutrients from the root system to the canopy. It affects equally all sweet orange varieties and can be transmitted by leafhoppers, contaminated budwood, and seedlings. Mandarins and its hybrids with sweet orange are usually resistant to the disease. Field management of CVC involves use of healthy plants, chemical control of the vectors, pruning of infected branches in old plants (older than six year old), and eradication of young (younger than five year old) diseased trees. The estimated year control cost in São Paulo State comes near to US\$ 100 millions.

Citrus leprosis - It is caused by the citrus leprosis virus $\mathrm{C}$ (CiLV-C), a member of the Cilevirus and vectored by the tenuipalpid mite Brevipalpus phoenicis. Citrus leprosis is one of the most devastating diseases of citrus in Brazil. It is estimated that in Sao Paulo State, more than US\$ 100 millions are spent to chemical control the vector mite. The disease does not seem to be systemic, inducing the formation of local lesions in fruits, leaves, and stems. Sweet oranges are all highly susceptible, while mandarins appear to be resistant or tolerant to the disease under field conditions.

Huanglonbing - In 2004, a disease known as huanglongbing or greening (HLB) was first detected in the state of Sao Paulo. The disease is classified as A1 subject to quarantine and is considered one of the most serious threats to the world's citriculture. HLB is caused by a phloem-limited bacterium tentatively named Candidatus Liberibacter spp., and is vectored by Diaphorina citri. No sources of resistance are known within the citrus group and the pathosystem is poorly known. All varieties of sweet orange and mandarins are high susceptible to HLB. Control has been carried out by using health young plants, eradication of infected plants in the orchard, and chemical spraying for the vector. It is a great concern in the citrus industry.

Citrus sudden death (CSD) - It is a new disease of citrus initially found in the northern regions of Sao Paulo State and the south of Minas Gerais in 1999/2000 affecting all scion varieties grafted onto Rangpur lime. Even though the incubation period of the disease is not certain, it has been observed that it can kill the plant in a period of 2-4 weeks. CSD is associated with Rangpur lime, rootstock highly tolerant to drought and partially responsible for the Brazilian competitiveness in citrus production. It is estimated that approximately 160 million plants are grafted onto Rangpur lime in Brazil. The control of this disease is based on the replacement of rootstocks by inarching or the renewal of the orchard using a new rootstock (new species or varieties). More than 1 million plants were eradicated, and the disease is a great risk to all citrus industry because the extensive use of Rangpur lime as rootstock.

Citrus canker - It is caused by Xanthomonas axonopodis pv. citri. In Brazil, the disease is classified as an A2 subject to quarantine and, therefore, should be eradicated by law. Besides the elimination of diseased plants, its management is based on the disinfestations of all potential vehicles that could carry the pathogen such as tools, boxes, people, trucks, etc. Other measures such as the use of windbreaks are also used to reduce the spread of the disease. Almost all citrus varieties are equally susceptible to canker, but at field conditions tolerance can be observed. It is estimated that the citrus industry spend more then US\$ 30 million on eradication program.

Citrus black spot - it is a disease with severe consequences to fruit quality. It is caused by the fungus Guignardia citricarpa. It is also considered a disease A2, subject to quarantine for export purposes. The control of black spot is based on 5 to 7 fungicide sprays per year, which has put many small and medium size producers out of business. There are no known sources of resistance.

Alternaria brown spot - Disease recently introduced into Brazilian orchards, the Alternaria brown spot is caused by the fungus Alternaria alternata alternata and has recently become one of the most important limiting factors of mandarin production in several regions of the states of Sao Paulo and Minas Gerais. It only affects mandarins and some hybrids.

Citrus tristeza - It is caused by the Citrus tristeza virus (CTV, Closteroviridae) and its symptoms are usually associated with two distinct forms. The stem pitting form of the disease reduces plant growth, the size of the fruit and productivity, while the quick decline form, found virtually in all citrus plants in Brazil, can kill the plant in a short period 
of time. In Brazil, the latter form of CTV is kept under control by using resistant rootstocks and cross protection using weak strains of the virus. All Citrus species are tolerant to the disease and no resistance has been described in nature. Poncirus trifoliata is resistant to the disease, and a single gene controls this characteristic.

Gummosis - It is caused by at least two Phytophthora species, $P$. citrophthora e $P$. parasitica. Initially, using sour orange as rootstock controlled the disease; however, with the appearance of citrus tristeza, this rootstock was completely excluded from the list of alternatives due to its high susceptibility to tristeza. Even though chemical control is still an option to manage the disease, gummosis is still an important problem in nurseries and young orchards. The degree of tolerance within citrus species varies from highly susceptible (C. sunki) to resistant ( $P$. trifoliata and its hybrids).

Besides the afore mentioned diseases, it is worth to mention the citrus blight disease (causal agent unknown) which only occurs in pants older than six years old.

Among the most desirable traits for rootstocks, drought tolerance is without doubts the most important one since citrus production in Brazil relies on the use of the highly tolerant Rangpur lime as a rootstock. With the appearance of citrus sudden death (CSD), which affects predominantly this species, new studies should be carried out to understand the molecular basis of drought tolerance in Rangpur lime.

Characteristics related to fruit quality such as soluble solids, acidity, color, concentration of vitamins and pigments explain in part the narrow genetic base of the Brazilian citriculture limiting the number of alternatives for the producers and restricting the commercialization of fresh fruit in international markets. No studies have been conducted to unveil the factors that control fruit quality in citrus.

\section{GENETIC MAPPING FOR DISEASE RE- SISTANCE IN CITRUS}

Genome-wide saturated genetic maps have become the basis for advanced studies in genetics, both for the identification and isolation of genes, and for the study of their structure, expression, and function. High-resolution maps of specific regions (i.e., close to genes of interest) are essential for the identification and isolation of genes. Map-based cloning comprises several steps: 1) development of a high resolution linkage map, 2) determination of the physical distance that will need to be covered by chromosome walking, 3 ) chromosome walking, using libraries harboring large genome fragments (BAC - bacterial artificial chromosome - libraries), and 4) confirmation that the target gene was indeed isolated by transformation aiming to complement a recessive allele or through demonstration that the corresponding region is altered or deleted in mutants.

In plants, several disease resistance genes from different species have been cloned and characterized. Numerous studies have been done using the identification of markers linked to resistance genes and the construction of BAC libraries. In citrus, chromosome walking technique has been attempted in order to locate the CTV resistance gene in Poncirus trifoliata in populations of Citrus taiwanica x P. trifoliata cv. Webber Fawcett, C. maxima cv. Chandler x P. trifoliata cv. Webber Fawcett, and citrumelo Sacaton $\mathrm{x}$ citrange Troyer.

Currently, almost 20 citrus genetic maps have been published, but no comparison amongst linkage groups from citrus species and related genera has been reported. In addition, only few of these maps correspond to pure species such as $C$. grandis, $C$ aurantium, C. latipies, C. volkameriana, C. sunki and P. trifoliata, while none of them represent a consensus map.

Some of these maps, , allowed the mapping of genes associated with agronomical characteristics of interest, such as dwarfing, fruit acidity, number of seeds, apomixes, male sterility, resistance to salinity, resistance to the nematode (T. semipenetrans) and disease resistance (gummosis caused by Phytophthora, citrus leprosis virus). Genetic mapping carried out at the Centro APTA Citros `Sylvio Moreira’ have located the resistance locus for CTV (linkage group I), and QRL (Quantitative Resistance Loci) associated with resistance to Phytophthora in P. trifoliata and Leprosis in Murcott tangor.

With the advent of large-scale sequencing and the various undergoing genome projects, the availability of sequences of different organisms has become one of the most important sources for generating molecular markers. Currently, these sources are being explored for the development of multiallelic markers, such as SSRs (single sequence repeats), SNPs (single nucleotide polymorphism) and RGAs (resistance gene analogs), which are often co-dominant, can be targeted to low saturated regions of the map, and their assessment can be easily automated. These characteristics make them ideal for the identification of cultivars and hybrids, for the saturation of linkage maps, and the localization and cloning of genes of interest.

The comparative mapping or synteny mapping represents another important application of genetic maps. Comparisons amongst genomic 
structures of different species, particularly gene homology and conservation of distances and linkage order in chromosomes, allow a better understanding of genome evolution.

\section{GENE EXPRESSION STUDIES: TRAN- SCRIPTOME AND METABOLOME}

The large volume of data generated by sequencing projects has created the need for new tools that allow large-scale gene expression analyses. Among them, the use of spotted expression or genotyping arrays has become the method of choice to study large scale expression of thousands of genes.

The study of global gene expression profiles has contributed to the identification of individual genes or groups of genes potentially associated with several metabolic pathways, resistance biotic and abiotic factors as well expression of QTL (Quantitative Trait Loci) at different environmental conditions. This knowledge not only contributes to the understanding of several biological models but also helps designing new strategies for genetic manipulation. In this regard, the generation of EST (Expressed Sequence Tags) libraries and the construction of arrays of cDNA clones is one of the most common approaches used for transcriptome studies in many species.

Currently, very little is known about global gene expression profiles of citrus. However, thousands of citrus ESTs were generated (see table 2) under conditions representing resistance and susceptibility to plant diseases, abiotic stress responses, flowering, and fruit development. These sequences belong to CitEST and Harvest database and are considered the largest EST database in the world. Therefore, the integration of the database with the construction of arrays for gene expression studies is of vital importance for the development of a clear understanding of host-pathogen interactions and other traits of interest.

One of the main objectives of transcriptome analysis is to generate knowledge through the sequencing of citrus ESTs under different conditions. The results of such experiments should carry out to focus on generating data that could be used for in silico differential expression studies involving contrasting conditions such as presence or absence of a given pathogen. These and other comparative results obtained from EST libraries indicated the need of validation of the data using strategies focusing a smaller number of genes such as qRT-PCR.

In order to have a complete view of the plant metabolism, it is necessary to integrate the advances in global gene expression with the actual physiol- ogy and biochemistry of the plant. In this regard, the most common approach involves the integration of transcriptomics and metabolomics. The metabolome consists of the global metabolites produced by a living organism of part of it. Differently from genomics, transcriptomics and proteomics, the study of the metabolome uses a large number of methods and experimental tools such as gas and liquid chromatography, mass spectrometry (FT-MS, GC-MS, HPLC-MS), spectroscopy (FTIR), and nuclear magnetic resonance (NMR).

The integration of transcriptomics and metabolomics could generate more accurate information about biochemistry and physiology of the plant providing details on processes such as transcription, translation, environmental effects and metabolite accumulation (phenotype).

\section{CITRUS GENOME}

The sequencing of the Citrus complete genome carried by the International Citrus Consortium (ICC) has already reached the goal. Researchers from Genoscope in France, JGI, the Institute of Genomic Applications in Italy, HudsonAlpha, and Spain's Lifesequencing used the Sanger approach to sequence the 296 million base genome of the Clementine mandarin to about 6.3 times coverage.

Currently the assembly of the genome comprises 1128 scafolds that are already in the server at Centro de Citricultura. Even though the bioinformatics of the Genome Sequencing effort is done abroad, all the data was downloaded to the server of the Centro de Citricultura and the services are being planned with an effort to co-opt people with expertise to help the development of such tools.

Both clementine and sweet orange databases are available at www.phytozome.net/clementine.php, and www.phytozome.net/citrus.php.

\section{GENETIC TRANSFORMATION OF CITRUS}

The creation of genetically modified citrus plants represents a significant advantage over the traditional methods of crop improvement. The main benefit of transformation is the introduction of new genetic traits without the alteration of the natural characteristics of the target variety or the high segregation patterns observed when highly heterozygous organisms are crossed.

The first genetically modified sweet orange was produced from embryogenic cells of the variety Washington Navel after co-culturing with Agrobacterium tumefaciens. On the other hand, the first trans- 
genic citrus plants were produced using sour orange and Mexican lime expressing the coat protein gene of CTV (pathogen-derived resistance), while the first transformed plant from adult tissue was produced in the 90's using sweet orange cv. Pineapple. Other reports of genetic transformation of citrus include sweet orange, sour orange, grapefruit, mandarin, and P. trifoliata.

The most common methods used for citrus transformation are either A. tumefaciens or biolisticbased approaches. However, the choice for a particular method depends on the tissue culture protocols available, the vector, the citrus variety or species, the expected efficiency, the capacity of regeneration, and the available materials. The plasmid vectors used for transformation via $A$. tumefaciens are classified as binary plasmids and should posses the transfer region within which the target gene will be introduced. This region also contains a selection marker (antibiotic resistance, herbicide resistance, etc.) and a reporter gene that favor the identification and selection of transformed plants. The final confirmation of transformed plants can be achieved by PCR using specific primers for the introduced gene.

Besides the traditional over-expression of a given homologous or heterologous gene, transformation can be carried out using interfering RNAs (iRNA). The process was originally observed in transgenic plants that failed to express the transgene and its homologous counterpart. In the proposed model, an excess of RNA can induced the formation of double stranded molecules that can be recognized by the enzyme “dicer" which degrades those into small RNA molecules known as interfering RNAs. Through the recruiting of the RISC (RNA silencing complex), all homologous sequences to these iRNA molecules will also be degraded resulting in the reduction of mRNA levels.

This mechanism has been gaining popularity among scientist due to its potential use for targeting specific genes. In plants, iRNA-based silencing has been proven to have systemic activity that can be induced by the presence of transgenes. RNA has been shown to be more than just a message carrier or an amino acid transporter, playing an active role in processing and regulation of gene expression.

\section{CITRUS BREEDING PROGRAM IN BRAZIL}

The challenges to citrus breeding do not imply that nothing has been done. Brazil, USA, Spain and Japan have active programs for citrus breeding involving integration of agronomy, genetic and molecular biology, including genome research.
The focus of the program in US is disease resistance (tristeza, nematodes, citrus canker and huanglongbing) and fruit quality, especially navels and grapefruits. In Spain the efforts are concentrated on Clementine mandarins for disease resistance (tristeza and psorosis) and fruit quality (seedless). The major interest of Japan is in Satsuma varieties, looking for disease resistance (Satsuma dwarf, tristeza, canker) and fruit quality. In these countries few has been done for breeding of rootstocks. It is important to point out that all the programs are supported by wide germplasm collections, and have incorporated several tools of biotechnology (from tissue culture to functional genome).

In Brazil citrus breeding programs have been conduced at Agronomic Institute, in Cordeirópolis (SP), and at Embrapa, in Cruz das Almas (BA). Embrapa's program involve germplasm evaluation, and agronomic test of new hybrids for rootstocks. The program in charge of Citriculture Center in Cordeirópolis involves following steps:

- Maintenance and evaluation of germplasm collection. The collection began in 30ths and has more than 1700 accesses which represent all citrus species and varieties. It is considered the greatest variety collection in the world. All field experimentation inside or outside of the Center starts with evaluation at small scale in the germplasm collections.

- Large-scale evaluation at field conditions.

The advent of molecular markers has accelerated genetic mapping and opened the possibility for a better evaluation of inheritance of disease resistance and other traits. Nevertheless, there are still questions on mapping populations and suitable approaches for phenotypic evaluation.

Using F1 progeny between C. sunki (susceptible) and P. trifoliata (resistant) and pseudo-test cross strategy we have mapped the tristeza resistance gene and QTLs for nematodes resistance. It is Important to point out that mapping information aim to characterize and to clone resistance genes, that can be use in the future in genetic transformation. For instance, the tristeza resistance gene of $P$. trifoliata could be used to make citrus also resistant to tristeza, specially sour orange, and in this way recover one the most important rootstock in the world that has resistance to gummosis and to blight or declinio (unknown etiology).

Supported by PRONEX the Citriculture Center of Agronomic Institute developed F1 populations between sweet orange $\mathrm{x}$ mandarin, sweet orange $\mathrm{x}$ tangor Murcott (a hybrid between sweet orange and mandarin), sweet orange $\mathrm{x}$ sweet orange, sweet orange x P. trifoliata, Sunki mandarin x P. trifoliata, 
among others. After selection of nucellar and zygotic individuals the hybrids have been used in mapping analysis for diseases inheritance, specially CVC, tristeza, gummosis and leprosis. Selection and mapping have been conduced by using molecular markers as RAPD, AFLP and SSR. Later on the hybrids will be tested at field conditions with possibility to origin commercial varieties. Over 1000 new different hybrids have been evaluated.

Besides diseases, one of the most important points for citrus breeding programs is the fruit quality. Both juice industry and the consumers do not accept great changes in fruit traits. Thus traits as Brix degree, acidity, and juice content cannot be significantly changed since specially in the juice production such parameters are essential for the final blending of the juices. On the other hand under tropical climate weather conditions the fruits of sweet orange do not develop suitable peel and juice color, although no expressive difference can be observed in other parameters (Brix and acidity). Since the genetics of those traits is certainly regulated by several genes it could be important to know the genes and their expression involved in the synthesis and degradation of fruit pigments during ripening.

TABLE 1 - Tree, production and FCOJ inventory of the Brazilian citrus industry agribusiness (Sources: Neves et al., 2010).

\begin{tabular}{|c|c|c|c|c|}
\hline Index & Oranges & $\begin{array}{l}\text { Mandarins } \\
\text { and hybrids }\end{array}$ & $\begin{array}{l}\text { Limes and } \\
\text { lemons }\end{array}$ & Total citrus \\
\hline Area in Brazil, 2007 (1,000 ha) & 920.7 & & & \\
\hline Producing area in Brazil, 2006 (1,000 ha) & 805.9 & 60.9 & 46.8 & 913.6 \\
\hline $\begin{array}{l}\text { Brazil in the world production share: } \\
\text { - \% production (2006) } \\
\text { - \% juice production }(2005 / 06) \\
\text { - \% juice export }(2005 / 06) \\
\end{array}$ & $\begin{array}{l}28.6 \\
60.0 \\
82.0 \\
\end{array}$ & 4.8 & 8.5 & 19.1 \\
\hline Area planted in the state of Sao Paulo, 2007 (1,000 ha) & 668.6 & $20.0^{*}$ & $30.0^{*}$ & $718.6^{*}$ \\
\hline $\begin{array}{l}\text { N. of trees, } 2007 \text { (millions) } \\
\text { - non-bearing } \\
\text { - bearing }\end{array}$ & $\begin{array}{l}217.5 \\
34.0 \\
183.5 \\
\end{array}$ & $\begin{array}{l}7.1 \\
0.7 \\
6.4\end{array}$ & $\begin{array}{l}8.6 \\
0.9 \\
7.7 \\
\end{array}$ & \begin{tabular}{|l}
233.2 \\
35.6 \\
197.6 \\
\end{tabular} \\
\hline $\begin{array}{l}\text { Production in the state of Sao Paulo, } 2007 \\
\text { Total weight (1,000 ton) } \\
\text { Boxes ( } 40.8 \mathrm{~kg}), 2007 \text { (millions) } \\
\text { Participation in processing: } \\
\text { FCOJ } 1996 \text { to } 2005 \text { (\%) } \\
\text { Processing NFC, } 1996 \text { to } 2005 \text { (\%) } \\
\text { Use of the fruits (\%): } \\
\text { - processed juice } \\
\text { - fresh fruit in the domestic market } \\
\text { - fresh fruit external }\end{array}$ & $\begin{array}{l}14,925 \\
365.8 \\
\\
97.0 \\
99.5 \\
\\
80.0 \\
19.7 \\
0.3^{* *} \\
\end{array}$ & $\begin{array}{l}660 \\
16.2 \\
\\
\\
1.0^{* *} \\
\end{array}$ & $\begin{array}{l}981 \\
24.0 \\
\\
\\
\\
10.0 \\
84.0 \\
6.0 * * \\
\end{array}$ & $\begin{array}{l}16,566 \\
406.0\end{array}$ \\
\hline $\begin{array}{l}\text { Processed juice in the 2007/08 crop (1,000 ton, } \\
\text { in units of FCOJ) } \\
\text { - n. of factories, } 2007 \text { (four major companies) } \\
\text { - n. of extractors, } 2007 \text { (four majors companies) }\end{array}$ & - & $\begin{array}{l}- \\
-\end{array}$ & - & $\begin{array}{l}1,420 \\
14 \\
1,004\end{array}$ \\
\hline $\begin{array}{l}\text { N. of plants produced per year in Sao Paulo, July } \\
2008 \text { (millions) } \\
\text { N. protected nurseries in Sao Paulo, July } 2008\end{array}$ & - & - & - & $\begin{array}{l}20.6 \\
556 \\
\end{array}$ \\
\hline
\end{tabular}

${ }^{*}$ No data available, estimated.

${ }^{*}$ Brazilian exports as compared to the production of the state of Sao Paulo 
TABLE 2 - The CitEST database.

\begin{tabular}{|l|l|l|l|l|}
\hline Species or Htbrids & $\begin{array}{l}\text { Total } \\
\text { Reads }\end{array}$ & Contigs & Singlets & Unigenes \\
\hline C. sinensis & 224,917 & 19,202 & 19,679 & 38,781 \\
\hline C. reticulata & 159,438 & 14,443 & 15,924 & 30,367 \\
\hline P. trifoliata & 77,325 & 7,141 & 7,657 & 14,798 \\
\hline C. aurantium & 11,520 & 954 & 3,897 & 4,851 \\
\hline C. medica & 480 & 93 & 215 & 308 \\
\hline Fortunella spp & 1,976 & 142 & 838 & 980 \\
\hline Citrumelo & 20,247 & 2,685 & 3,079 & 5,764 \\
\hline C. macrophylla & 1,902 & 134 & 498 & 632 \\
\hline Citrange & 848 & 70 & 564 & 634 \\
\hline C. reshni & 2,784 & 331 & 1,548 & 1,879 \\
\hline C. aurantifolia & 10,560 & 1,251 & 2,276 & 3,527 \\
\hline C. latifolia & 10,560 & 994 & 2,364 & 3,358 \\
\hline C. limettiodes & 10,080 & 224 & 971 & 1195 \\
\hline C. sunki & 9,120 & 317 & 715 & 1032 \\
\hline C. limonia & 20,733 & 1035 & 1771 & 2806 \\
\hline All species & 562,490 & - & - & - \\
\hline
\end{tabular}

\section{Basic assumptions}

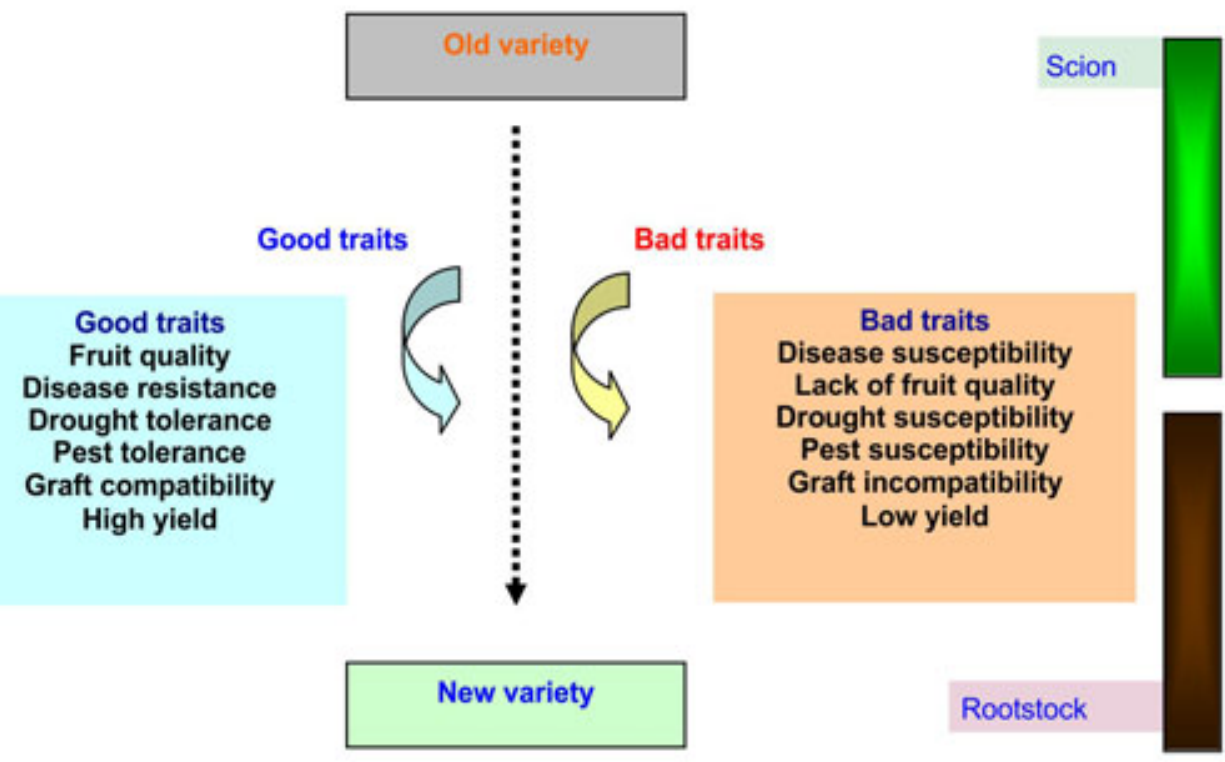




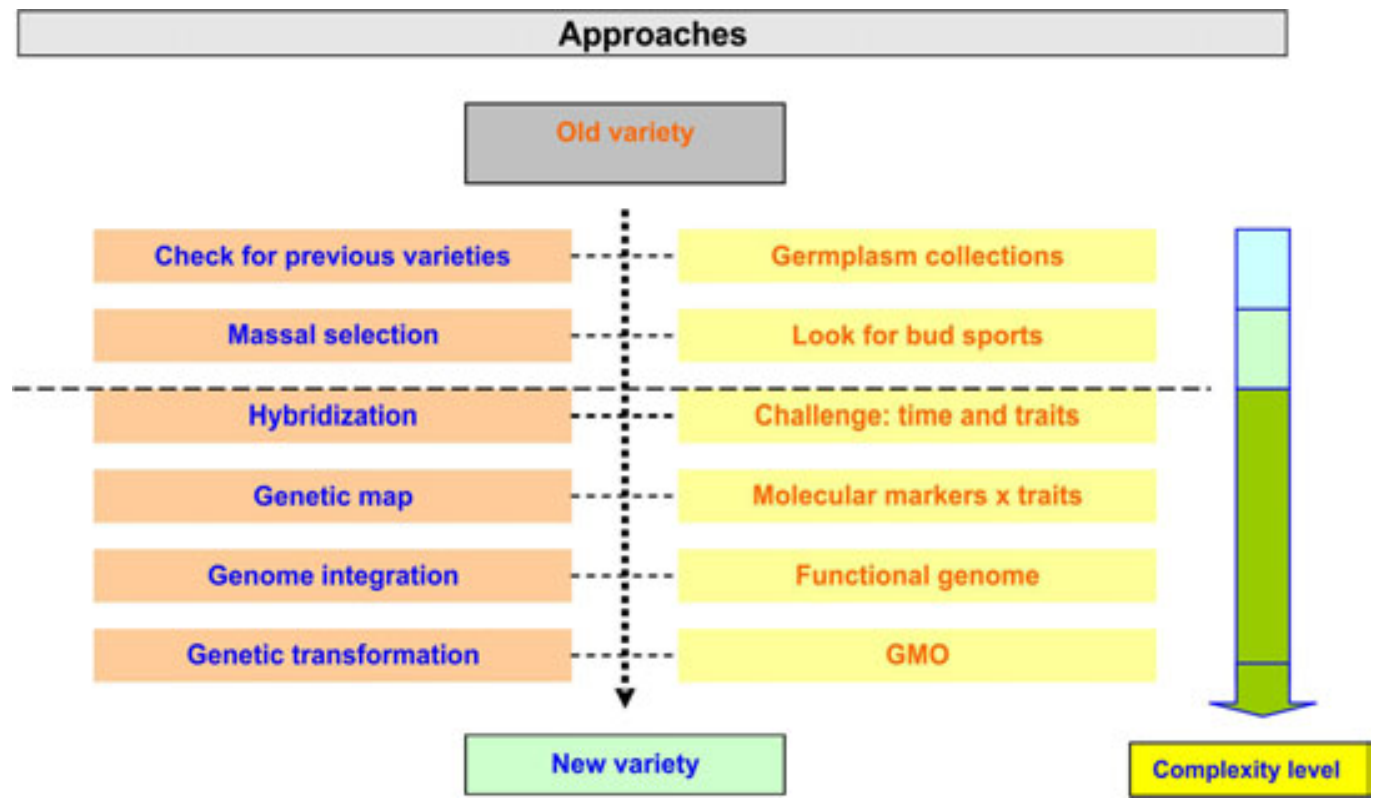

FIGURE 1 - General approaches for citrus breeding programs.

\section{REFERENCES}

BASTIANEL, M.; OLIVEIRA, A.C.; CRISTOFANI, M.; MACHADO, M.A. Diversidade genética entre híbridos de laranja Pêra com tangor Murcott avaliada por AFLP e RAPD. Pesquisa Agropecuária Brasileira, Brasília, v. 42, n. 5, p. 779-784, 2006.

BASTIANEL, M.; CRISTOFANI-YALY, M.; OLIVEIRA, A.C.; FREITAS-ASTÚA, J.; GARCIA, A; A.F.; RESENDE, M.D.V.; RODRIGUES, V.; MACHADO, M.A.. Quantitative trait loci analysis of citrus leprosis resistance in an interspecific backcross family of (Citrus reticulata Blanco C. sinensis L. Osbeck) C. sinensis L. Osb. Euphytica, Wageningen, v.169, p.101-111, 2009.

BOAVA, L.P; CRISTOFANI-YALY, M.; MAFRA, V.S; KUBO, K.S.; KISHI, L.T; TAKITA, M.A ; RIBEIRO-A. M.; MACHADO, M.A . Global gene expression of Poncirus trifoliata, Citrus sunki and their hybrids under infection of Phytophthora parasitica. BMC Genomics, Chichester, v. 12, p. 39, 2011.

CAI, Q; GUY, C.L.; MOORE, G.A. Extension of the linkage map in Citrus using random amplified polymorphic DNA (RAPD) markers and RFLP mapping of cold-acclimation-responsive loci. Theoretical Applied Genetics, Berlin, v.89, p.606-14, 1994.
CHENG, F.S.; ROOSE, M.L. Origin and inheritance of dwarfing by the citrus rootstock Poncirus trifoliata Flying Dragon. Journal of the American Society for Horticultural Science, Alexandria, v.120, p.28691, 1995.

CRISTOFANI, M.; MACHADO, M. A; GRATTAPAGLIA, D. Genetic linkage maps of Citrus sunki Hort. ex. Tan. and Poncirus trifoliata (L.) Raf. and mapping of citrus tristeza virus resistance gene. Euphytica, Dordrecht, v.109, p. 25-32, 1999.

CRISTOFANI, M.; MACHADO, M.A.; NOVELLI, V.M.; SOUZA, A.A.; TARGON, M.L.P.N. Construction of linkage maps of Poncirus trifoliata and Citrus sunki based on microsatellite markers. In: INTERNATIONAL SOCIETY CITRICULTURE CONGRESS, 9., 2000, Orlando. Proceedings... p.175-8

CRISTOFANI, M.; NOVELLI, V.M.; OLIVEIRA, A.C.; OTAVIANO, A.R.; SOUZA, A.A.; MACHADO, M.A. Identificação de híbridos de cruzamentos interespecíficos em citros utilizando marcadores RAPD e SSR. Laranja, Cordeirópolis, v.22, p. 231-241, 2001.

CRISTOFANI-YALY, M.; NOVELLI, V. M.; BASTIANEL, M.; MACHADO, M.A. Transferability and level of heterozygosity of microsatellite markers in citrus species. Plant Molecular Biology Reporter, Dordrecht, v. 29, n.2, p.418-42, 2011. 
DENG, Z., HUANG, S.; XIAO, S.; GMITTER, F.G. Development and characterization of SCAR markers linked to the citrus tristeza virus resistance gene from Poncirus trifoliata. Genome, Ottawa, v.40, p.697-704, 1997.

DENG, Z.; HUANG, S.; LING, P.; YU, C.; TAO, Q.; CHEN, C.; WENDELL, M. K.; ZHANG, H.B.; GMITTER, F.G. JR. Fine genetic mapping and BAC contig development for the citrus tristeza virus resistance gene locus in Poncirus trifoliata (Raf.). Molecular Genetics and Genomics, Berlin, v.265, p.739-47, 2001.

DOMINGUEZ, A.; FAGOAGA, C.; NAVARRO, L.; MORENO, P.; PEÑA, L. Efficient production of transgenic citrus plants expressing the coat protein gene of citrus tristeza virus. Molecular Genetics and Genomics, Berlin, v.267, p. 544-56, 2002.

DURHAN, R.E.; LIOU, P.C.; GMITTER, JR. F.G.; MOORE, G.A. Linkage of restriction fragment length polymorphism and isozymes in Citrus. Theoretical and Applied Genetics, Berlin, v.84, p. 39-48, 1992.

FANG, D.Q., FEDERICI, C.T., ROOSE, M.L. Development of molecular markers linked to a gene controlling fruit acidity in citrus. Genome, Ottawa, v.40, p. 841-9, 1997.

FANG, D.Q.; FEDERICI, C.T.; ROOSE, M.L.. A high-resolution map of citrus tristeza virus resistance gene region in Poncirus trifoliata (L.) Raf. Genetics, Bethesda, v.150, p.883-9, 1998.

FREITAS-ASTÚA, J.; BASTIANEL, M.; LOCALIFABRIS, E.C.; NOVELLI, V. M.; SILVA-PINHATI, A.C.; BASILIO, A.C.P.; TARGON, M.L.P.N.; MACHADO, M.A. Differentially expressed stressrelated genes in the compatible citrus-Citrus leprosis virus interaction. Genetics and Molecular Biology, Ribeirão Preto, v.30, p. 980-1018, 2007.

GARCIA, R.; ASINS, M.J.; FORNER, J.; CARBONELL, E.A. Genetic analysis of apomixis in Citrus and Poncirus by molecular markers. Theoretical and Applied Genetics, Berlin, v.99, p. 511-8, 1999.

GARCÍA, M.R.; ASÍNS, M.J.; CARBONELL, E.A. QTL analysis of yield and seed number in Citrus. Theoretical and Applied Genetics, Berlin, v.101, p.487-493, 2000.
GMITTER JR., F.G.; XIAO, S.Y.; HUANG, S.;HU., X.L; GARNSEY, S.M.; DENG, Z. A localized linkage map of the citrus virus resistance gene region. Theoretical and Applied Genetics, Berlin, v.92, p.688-695, 1996.

GOLDSCHMIDT, E.E. Regulatory aspects of chlorochromoplast interconversions in senescing Citrus fruit peel. Israel Journal of Botany, Jerusalem, v.37, p.123-30, 1988.

GROSS, J. Carotenoids: pigments in fruits. London: Academic Press, 1987.

GUTIÉRREZ-E, M.A.; LUTH, D.; MOORE, G.A. Factors affecting Agrobacterium-mediated transformation in Citrus and production of sour orange (Citrus aurantium L.) plants expressing the coat protein gene of citrus tristeza virus. Plant Cell Reports, Berlin, v.16, p.745-53, 1997.

HIDAKA, T.; OMURA, M. Transformation of Citrus protoplasts by electroporation. Journal of the Japanese Society for Horticultural Science, Tokyo, v.62, p.371-6, 1993.

HIDAKA, T.; OMURA, M.; UGAKI, M.; TOMIYAMA, M. Agrobacterium-Mediated Transformation and Regeneration of Citrus spp from suspension cells. Japanese Journal of Breeding, Tokyo, v.40, p.199-207,1990.

HIRAI, M.Y.; YANO, M.; GOODENOWE, D.B.; KANAYA, S.; KIMURA. T.; AWAZUHARA, M.; ARITA, M.; FUJIWARA, T.; SAITO, K. Integration of transcriptomics and metabolomics for understanding of global responses to nutritional stresses in Arabidopsis thaliana. Proceedings of the National Academy of Sciences of the United States of America, Washington, v.101, p.10205-10, 2004.

JARREL, D.C.; ROOSE, M.L.; TRAUGH, S.N.; KUPPER, R.S. A genetic map of citrus based on the segregation of isozymes and RFLPs in an intergeneric cross. Theoretical and Applied Genetics, Berlin, v.84, p.49-56, 1992.

KANEYOSHI, J.; KOBAYASHI, S.; NAKAMURA, Y. A simple and efficient gene transfer system of trifoliate orange. Plant Cell Reports, Berlin, v.13, p.541-5, 1994. 
KANYUKAKATO, M.; IKOMA, Y.; MATSUMOTO, H.; SIGIURA, M.; HYODO, H.; YANO, M. Accumulation of carotenoids and expression of carotenoid biosynthetic genes during maturation in citrus fruit. Plant Physiology, Minneapolis, v.134, p. 824-37, 2004.

Ing, P.; Duncan, L.W.; Deng, Z.; Dunn, D.; Hu, X.; Huang, S.; Gmitter, F.G. Inheritance of citrus nematode resistance and its linkage with molecular markers. Theoretical and Applied Genetics, Berlin, v.100, p.1010-7, 2000.

LIOU, P.C. A molecular study of the Citrus genome through restriction fragment length polymorphism and isozyme mapping. 1990. Dissertation (PhD) - University of Florida, Gainsville, 1990.

LOCALI, E.C.; FREITAS-ASTUA, J.; SOUZA, A.A.; TAKITA, M.A.; ASTUA-MONGE, G.; ANTONIOLI, R.; KITAJIMA, E.W.; MACHADO M.A. Development of a molecular tool for the diagnosis of leprosis, a major threat to the citrus production in the Americas. Plant Disease, Saint Paul, v.87, p.1317-21, 2003.

LURO, F.; LAIGRET, F.; LORIEUX, M.; OLLITRAULT, P. Citrus genome mapping with molecular markers: two maps obtained by segregation analysis of progeny of one intergeneric cross. In: INTERNATIONAL SOCIETY OF CITRICULTURE CONGRESS, 2., 1996, Sun City. Proceedings.... p.862-6.

MACHADO, M.A.; COLLETA FILHO, H.D.; TARGON, M.L.N.P.; POMPEU JR., J. Genetic relationship of Mediterranean mandarins (Citrus deliciosa Tenore) using RAPD markers. Euphytica, Wageningen, v.92, p.321-6, 1996.

MACHADO, M.A.; CRISTOFANI-YALY, M.; AMARAL, A.M.; OLIVEIRA, A.C. Genética, melhoramento e biotecnologia. In: MATTOS JUNIOR; D.; NEGRI. J.D.; PIO, R.M; POMPEU JUNIOR, J. (Org.). Citros. Campinas: Instituto Agronômico e Fundag, 2005. p. 223-264.

MESTRE, P.F.; ASÍNS, M.J.; PINA, J.A.; CARBONELL, E.A.; NAVARRO, L. Molecular markers flanking citrus tristeza virus resistance gene from Poncirus trifoliata (L.) Raf. Theoretical and Applied Genetics, Berlin, v.94, p.458-64, 1997.
MOORE, G.A.; JACANO, C.C.; NEIDIGH, J.L. Agrobacterium-mediated transformation of citrus stem segments and regeneration of transgenic plants. Plant Cell Reports, Berlin, v.11, p. 238-42, 1992.

MOORE, G.A.; LUTH, D.; KAPLAN, F.; GUTIÉRREZ-E, M.A. Genetic transformation in citrus. In: JAIN, S.M.; MINOCHA, S.C. (Ed.). Molecular biology of woody plants. Boston: Kluwer Academic Press, 2000. v.2, p. 227-243.

NOVELLI, V.M.; CRISTOFANI, M.; MACHADO, M.A. Evaluation of microsatellite markers in cultivars of sweet orange Citrus sinensis (L.) Osbeck. Acta Horticulturae, The Hague, v. 535, p.47-50., 2000.

NOVELLI, V.M.; CRISTOFANI, M.; SOUZA, A.A.; MACHADO, M.A. Development and characterization of polymorphic simple sequence repeats (SSRs) in sweet orange (Citrus sinensis L. Osbeck). Genetics and Molecular Biology, Ribeirão Preto, v.29, n.1, p.90-96, 2006;

NOVELLI, V.M.; TAKITA, M.A.; MACHADO, M.A. Identification and analysis of Single Nucleotide Polymorphisms (SNPs) in Citrus. Euphytica, Wageningen, v.138, p. 227-237, 2004b.

NUNES, L.R.; ROSATO, Y.B.; MUTO, N.H.; YANAI, G.M.; DA SILVA, V.S.; LEITE, D.B.; GONÇALVES, E.R.; DE SOUZA, A.A.; COLLETAFILHO, H.D.; MACHADO, M.A.; LOPES, S.L.; COSTA DE OLIVEIRA, R. Microarray analyses of Xylella fastidiosa provide evidence for coordinated transcription control of laterally transferred elements. Genome Research, Cold Spring Harbor, v.13, p.570-8, 2003.

OLIVEIRA, A.C.; BASTIANEL, M.L.; CRISTOFANI, M.; MEDINA, C.L.; MACHADO, E.C.; GOLDMAN, G.H.; MACHADO, M.A. Mapeamento genético de marcadores AFLP ligados a locos de resistência quantitativa de citros à Xylella fastidiosa. In: CONGRESSO NACIONAL DE GENÉTICA, 48., 2002. Águas de Lindóia. Anais...

OLIVEIRA, A.C., GARCIA, A.; CRISTOFANI, M.; MACHADO, M.A. Identification of citrus hybrids through the combination of leaf apex morphology and SSR markers. Euphytica, Wageningen, v.128, p.397-403, 2002. 
Oliveira, A.C.; Machado, M.A. In vitro embryo rescue of citrus and identification of hybrid morphometric features and molecular markers. In: INTERNATIONAL SOCIETY CITRICULTURE CONGRESS, 9., 2000, Orlando. Proceedings... p.172-4.

OLIVEIRA, A.C.; VALLIM, M.A.; SEMIGHINI, C.P.; ARAÚJO, W.L.; GOLDMAN, G.H.; MACHADO. M.A. Quantification of Xylella fastidiosa from citrus trees by real-time polymerase chain reaction assay. Phytopathology, Saint Paul, v.92, p.1048-54, 2002.

OLIVEIRA, A.C.; BASTIANEL, M.; CRISTOFANI-YALI, M.; AMARAL, A.M.; MACHADO, M.A. Development of genetic maps of the citrus varieties Murcott tangor and Pêra sweet orange by using fluorescent AFLP markers. Journal of Applied and Genetics, Berlin, v.48, p.219-231, 2007.

OLIVEIRA, R.P.; CRISTOFANI, M.; MACHADO, M.A. Genetic linkage maps of Pêra sweet orange and Cravo mandarin with RAPD markers. Pesquisa Agropecuária Brasileira, Brasília, v.39, p.159-65, 2004.

PALMIERI, D. A.; NOVELLI, V. M.; BASTIANEL, M.; CRISTOFANI, M.; ASTUA-MONGE, G.; CARLOS, E.F.; OLIVEIRA, A.C.; MACHADO, M.A. Frequency and distribution of microsatellites from ESTs of citrus. Genetics and Molecular Biology, Ribeirão Preto, v.30, p.1009-1018, 2007.

RUIZ, C., PAZ BRETO, M., ASÍNS, M.J. A quick methodology to identify sexual seedlings in citrus breeding programs using SSR markers. Euphytica, Wageningen, v.112, p. 89-94, 2000.

SIMONE, M.D.; RUSSO, M.P.; PULEO, G.; MARSAN, P.A.; LORENZONI, C.; MAROCCO, A.; RECUPERO, G.R. Construction of genetic maps for Citrus aurantium and C. latipes based on AFLP, RAPD and RFLP markers. Fruits, Paris, v.53, p.38390, 1998.
SIVIERO, A.; CRISTOFANI-YALY, M.; FURTADO, E.L; GARCIA, A.A.F.; COELHO, A. S.; MACHADO, M.A. Identification of QTLs associated with citrus resistance to Phytophthora gummosis. Journal of Applied and Genetics, Berlin, v.47, p.23-28, 2006.

SIVIERO, A. Avaliação de métodos de inoculação de Phytophthora parasítica e mapeamento de QTLs de resistência em híbridos de Citrus sunki vs. Poncirus trifoliata à gomose. $2001.117 \mathrm{f}$. Tese (Doutor) - Faculdade de Ciências Agronômicas, Universidade Estadual Paulista, Botucatu, 2001.

SIVIERO, A.; CRISTOFANI, M.; BOAVA; L.; MACHADO, M.A. Mapeamento de QTLs associados à produção de frutos e sementes em híbridos de Citrus sunki x Poncirus trifoliata. Revista Brasileira de Fruticultura, Jaboticabal, v.4, p.741-3, 2002.

TOZLU, I.; GUY, C.L.; MOORE, G.A. QTL analysis of morphological traits in an intergeneric BC1 progeny of Citrus and Poncirus under saline and non-saline environments. Genome, Ottawa, v.42, p.1020-9, 1999a.

TOZLU, I.; GUY, C.L.; MOORE, G.A. QTL analysis of $\mathrm{Na}$ and $\mathrm{Cl}$ accumulation related traits in an intergeneric BC1 progeny of Citrus and Poncirus under saline and non-saline environments. Genome, Ottawa, v.42, p.692-705, 1999b.

TUSHER, V.G.; TIBSHIRANI, R.; CHU, G. Significance analysis of microarrays applied to the ionizing radiation response. Proceedings of the National Academy of Sciences of the United States of America, Washington, v.98, p.5116-20, 2001.

YANG, Z.N.; YE, X.R.; CHOI, S.; MOLINA, J.; MOONAN, F.; WING, R.A; ROOSE, M.I.; MIRKOV, T.E. Construction of a $1.2 \mathrm{Mb}$ contig including the citrus tristeza virus resistance gene locus using a bacterial artificial chromosome library of Poncirus trifoliata (L.) Raf. Genome, Ottawa, v.44, p.382-93, 2001. 